\title{
RANCANG BANGUN SISTEM TRY OUT BERBASIS PAPERLESS UNTUK EVALUASI HASIL
} BELAJAR SISWA DENGAN MVC

\author{
Ramadhan Rakhmat Sani ${ }^{1}$, Defri Kurniawan ${ }^{2}$ \\ ${ }^{1},{ }^{2}$ Fakultas Ilmu Komputer, Universitas Dian Nuswantoro, Semarang \\ Email: ${ }^{1}$ ramadhan_rs@dsn.dinus.ac.id, ${ }^{2}$ defri.kurniawan@dsn.dinus.ac.id
}

(Naskah masuk: 26 Oktober 2018, diterima untuk diterbitkan: 13 Februari 2019)

\begin{abstract}
Abstrak
Sistem pelaksanaan Ujian Nasional di Indonesia saat ini mulai beralih menggunakan komputer sebagai media dalam pelaksanaannya menggantikan sistem yang lama. Sebagai bentuk dukungan dalam mengurangi penggunaan kertas dalam pembelajaran dan evaluasi baik lembar soal maupun materi di sekolah. Tujuan dari penelitian ini adalah menghasilkan purwarupa model sistem tryout berbasis paperless untuk evaluasi hasil belajar siswa untuk menggantikan pemakaian kertas dengan konsep yang diberikan oleh media komputer. Sehingga memberikan keuntungan dalam efisiensi waktu dan biaya, mengurangi kecurangan serta mempercepat dalam proses evaluasi. Metode yang digunakan dalam pengembangan aplikasi ini menggunakan Rapid Application Development (RAD) yang meliputi tahapan analisa kebutuhan perangkat lunak, perancangan perangkat lunak, implementasi perangkat lunak dan pengujian perangkat lunak dengan penerapan konsep Sistem Development Life Cycle (SDLC) sehingga cepat untuk dievaluasi oleh pengguna. Untuk bahasa pemodelan sistem menggunakan UML (Unified Modeling Language) yang terdiri use case diagram, sequential diagram dan pemodelan database. Penggunaan framework Codeigniter memberikan kemudahan dalam konsep Object Oriented Programing (OOP) dengan menggunakan arsitektur web MVC (Model, View, Controller). Pemisahan logika pembuatan kode pada tampilan website menjadikan lebih terstruktur, sederhana dan aman sehingga memberikan kemudahan bagi developer maupun programmer dalam pengembangannya tanpa harus dimulai dari awal. Hasil pengujian sistem menggunakan blackbox testing menunjukan hasil yang baik dan sudah mencapai $90 \%$ dari prinsip usability yang telah diimplementasikan.
\end{abstract}

Kata kunci: paperless, try out, $M V C, R A D$, blackbox testing

\section{DESIGN AND DEVELOPMENT OF PAPERLESS TRYOUT SYSTEM FOR EVALUATION OF STUDENT LEARNING RESULTS USING MVC}

\begin{abstract}
The current National Examination System in Indonesia has begun to switch to using computers as a medium in its implementation to replace the old system. As a form of support in reducing paper use in learning and evaluating both question sheets and material at school. The purpose of this study was to produce a prototype paperless based tryout system model for evaluating student learning outcomes to replace paper use with the concepts provided by computer media. So as to provide benefits in time and cost efficiency, reduce fraud and accelerate the evaluation process. The method used in the development of this application uses Rapid Application Development (RAD) which includes the stages of software requirements analysis, software design, software implementation and software testing with the application of the concept of System Development Life Cycle (SDLC) so that it is quickly evaluated by users. For system modeling languages use UML (Unified Modeling Language) which consists of use case diagrams, sequential diagrams and database modeling. The use of CodeIgniter framework provides convenience in Object Oriented Programing (OOP) concepts using the MVC web architecture (Model, View, Controller). Separation of logic in making code on the website display makes it more structured, simpler and safer so that it makes it easy for developers and programmers to develop without having to start from scratch. The results of testing the system using blackbox testing showed good results and has reached $90 \%$ of the usability principle that has been implemented.
\end{abstract}

Keywords: paperless, try out, $M V C, R A D$, blackbox testing 


\section{PENDAHULUAN}

Kemajuan di bidang teknologi informasi dan komputer mendorong lahirnya sistem paperless guna mendapatkan alternatif lain dalam mengolah dan membaca dari berbagai dokumen (Zhang, 2017). Ujian Nasional Berbasis Komputer (UNBK) merupakan salah satu penerapan dari sistem paperless. Beberapa keuntungan penerapan sistem paperless untuk pelaksanaan UN berdasarkan penelitian (Pakpahan, 2016), yaitu penghematan anggaran sehingga pemerintah tidak perlu mengeluarkan biaya untuk mencetak naskah ujian, kemudahan distribusi, dapat menjangkau seluruh wilayah, kecepatan dalam memperoleh informasi hasil ujian (penilaian), dan dapat mencetak sertifikat setelah ujian selesai. Beberapa penelitian terkait penerapan sistem paperless dilakukan dengan tujuan untuk mengurangi penggunaan kertas (Septanto \& Ananto, 2015) dan juga memberikan umpan balik yang baik dalam melakukan pemeriksaan yang lebih sering, sehingga pengawasan berjalan dengan efektif (Weidong, 2010). Pada penelitian (Arief \& Suryani, 2016), penggunaan sistem paperless pada ujian dapat mengurangi resiko kecurangan siswa dan pihak lainnya serta membuat pengawasan menjadi lebih mudah. Sehingga sistem paperless menjadi suatu rekomendasi solusi terhadap pelaksanaan ujian.

Try Out merupakan salah satu cara yang dilakukan oleh sekolah dan pihak terkait dalam melakukan evaluasi untuk mempersiapkan siswa menghadapi ujian nasional (Yulia, 2016). Dalam Bahasa Indonesia, try out memiliki arti percobaan. Try out dengan bantuan komputer menurut (Yulia, et al., 2016) memiliki dampak positif yaitu dapat membiasakan siswa dalam menghadapi ujian nasional, seperti mengisi lembar jawab komputer dan dari kegiatan try out, siswa memperoleh gambaran mengenai materi, jenis maupun bentuk soal ujian nasional yang akan diujikan. Dalam pelaksanaanya, konten soal try out yang sesuai dengan kisi-kisi ujian nasional akan memberikan hubungan positif yang signifikan terhadap hasil ujian nasional siswa (Ridho, 2011). Pelaksanaan try out juga berpengaruh terhadap mutu pendidikan pada sekolah (Hasmiah, 2014). Penelitian (Narimo, 2014) mengungkapkan bahwa try out berkorelasi secara positif dan signifikan terhadap hasil ujian nasional. sehingga semakin tinggi hasil try out maka akan diikuti dengan tingginya hasil nilai ujian nasional.

Try out berbasis paperless tentu juga memiliki dampak negatif seperti halnya penggunaan komputer untuk ujian nasional yaitu dapat menimbulkan sakit mata hingga pegal karena berlama-lama berada di depan komputer selama 120 menit untuk satu mata pelajaran (Pojoksatu, 2017). Ketersediaan jumlah perangkat komputer yang memadai pada tiap sekolah, jaringan komputer baik internet maupun lokal merupakan faktor-faktor yang mempengaruhi keberhasilan pelaksanaan ujian berbasis komputer (Pakpahan, 2016). Adapun sistem ujian yang diterapkan secara online, memiliki beberapa manfaat atau benefit yaitu pada kecermatan penilaian, efisiensi waktu penilaian, kepraktisan, keefektifan penilaian yang cukup tinggi, serta kerahasian dan pengamanan jawaban yang tinggi (Widikda, et al., 2013). Bagaimana mengembangkan sistem berbasis paperless untuk ujian try out merupakan topik pada penelitian ini.

Penelitian mengenai pengembangan sistem try out berbasis paperless pernah dilakukan pada penelitian sebelumnya. Dalam penelitian (Raharjo, 2012) merancang dan membuat aplikasi tryout ujian nasional berbasis web di sekolah dengan tujuan untuk memudahkan siswa dan guru untuk melakukan ujian secara paperless. Hasil pengujian menunjukkan bahwa perancangan berbasis web tersebut memudahkan siswa dalam mengerjakan soal-soal yang bersifat acak. Dalam (Dewi, 2014) membuat suatu sistem pendukung untuk pelaksanaan ujian seleksi masuk calon mahasiswa baru secara online. Pada implementasinya sebuah prototype aplikasi iLearning education marketing yang dapat memaksimalkan kegiatan dalam melayani calon mahasiswa baru dan menjadikan media pelayanan dan informasi secara umum. Sedangkan (Utomo \& Kustijono, 2015) melakukan pengembangan sistem ujian online pada soal pilihan ganda dengan menggunakan software wondershare quiz creator. Dengan tujuan untuk mendeskripsikan kelayakan soal pilihan ganda yang ditinjau dari sisi validitas, kepraktisan dan efektivitas. Mengadaptasi penelitian pengembangan model 4D yaitu tahap pendefinisian (define), perancangan (design), pengembangan (develop), dan penyebaran (disseminate). Hasil yang didapat pada penelitian tersebut berkategori sangat baik dan layak untuk digunakan. (Sani \& Kurniawan, 2018) juga melakukan analisis dan perancangan ujian online untuk bahan evaluasi siswa yang membantu dalam memodelkan pembuatan aplikasinya. Namun arsitektur web model apa yang paling sesuai dalam mengembangkan sistem try out berbasis paperless.

Di dalam perancangan web tentunya design pattern model digunakan sebagai solusi generik untuk masalah-masalah yang umum ditemui oleh para developer dalam membuat aplikasi. Karena pattern yang digunakan disini berdiri sendiri. artinya ditentukan oleh developer akan menjadi kendala apabila pola atau framework yang digunakan tidak sama dengan yang lainnya dan menjadikan sulit dalam melakukan pengembangannya. Sehingga jika ada suatu perubahan akan mengubah lainnya.

Kinerja suatu aplikasi web dipengaruhi oleh banyaknya pengguna (user) saat mengakses dan kompleknya transaksi data yang dilakukan menjadi permasalahan yang dihadapi dalam membangun aplikasi web (Lawi, 2016), sehingga perlu pemilihan arsitektur web yang tepat agar kinerja web dapat optimal. Model-View-Controller (MVC) merupakan salah satu arsitektur web yang dapat menghasilkan aplikasi yang modular, sehingga dapat mengurangi 
kompleksitas pada desain arsitektur, meningkatkan fleksibilitas, dan memiliki kemampuan penggunaan kembali / reusability (Jailia, 2016). Dalam proses pengembangan perangkat lunak banyak pendekatan dalam proses pembuatannya seperti berbasis objek. Akan tetapi akan lebih terstruktur lagi apabila memakai arsitektur MVC. Alasan penggunaan MVC model yaitu dapat digunakan kembali, praktik terbaik untuk pengembang karena sangat familiar dengan terminologinya sehingga dapat memberikan solusi yang berorientasi terhadap masalah Sehingga MVC model dinilai tepat sebagai arsitektur web pada sistem try out yang dibangun.

Dalam pengembangan sistem terdapat beberapa metodologi pengembangan yang ada, pengembangan konvensional seperti waterfall terdapat kelemahan dimana terdapat batas waktu yang cukup lama pada setiap tahapannya, dan tidak akan bermanfaat apabila belum diselesaikan seluruhnya (Noertjahyana, 2002). Selain itu dalam prakteknya, tahapan satu dengan lainnya pada waterfall dapat saling tumpang tindih, saat tahap desain ditemukan masalah pada requirement, saat coding ditemukan masalah pada design dan seterusnya (Sommerville, 2015). Rapid Application Development (RAD) merupakan metode yang muncul untuk mengatasi kelemahan pada model sebelumnya (waterfall) dengan menggabungkan teknik khusus dan computer tools agar dapat mempercepat tahap analisis, desain dan implementasi untuk mendapatkan bagian penting pada sistem untuk dievaluasi oleh pengguna (Dennis, 2009). Supaya dapat diterima oleh konsumen dan dapat dikembangkan dengan mudah, menghemat waktu dan memangkas biaya serta hasil yang berkualitas, maka dipilih metode pengembagan Rapid Application Development (RAD) sebagai alternatif yang mampu mengatasi masalah tersebut. Dimana proses desain ulang dapat dilakukan bersamaan saat dikembangkan, pengiriman lebih mudah karena lebih banyak menggunakan potongan-potongan script. Memunculkan produk sederhana dan nyaman dengan bantuan beberapa software pendukung. Sehingga penggunaan metode pengembangan RAD dipilih untuk mengembangkan sistem try out berbasis paperless dengan menggunakan MVC model.

\section{METODE}

\subsection{RAPID APPLICATON DEVELOPMENT MODEL}

Mengadopsi dari waterfall model dan pembangunan dalam waktu tidak lama (Pressman, 2014) adalah suatu pendekatan berorientasi objek terhadap pengembangan sistem yang mencakup suatu metode pengembangan serta perangkat-perangkat lunak (Aswati \& Siagian, 2016). Terdapat tiga fase dalam RAD yang melibatkan penganalisis dan pengguna dalam tahap penilaian, perancangan, dan penerapan yang digambarkan pada Gambar 1 .

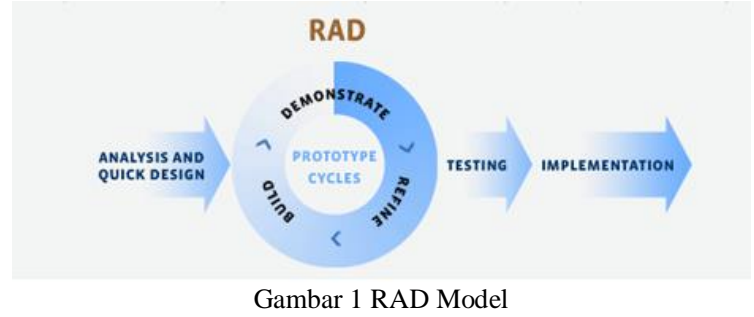

\subsection{MODEL VIEW CONTROL (MVC)}

Framework menawarkan kemudahan dalam konsep objek oriented programing (OOP) dengan menggunakan metode MVC (Model, View, Controller); (Prasetya, 2011); (Putri \& S, 2016). Dengan memisahkan logika pembuatan kode dengan tampilan website dengan menggunakan pola desain (Hameed, 2014) yang menjadikan lebih terstruktur dan sederhana sehingga memberikan kemudahan bagi developer maupun programmer tanpa harus dari awal dalam pembuatannya (Sophan \& Kurniawati, 2018).

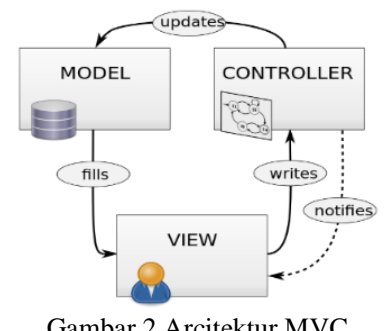

Didalam website dinamis terdapat 3 hal pokok yaitu basis data, tampilan halaman website dan controller logika aplikasi berkaitan dengan MVC seperti pada Gambar 2. Model memberikan gambaran tentang struktur data dalam website yang berisikan class dan fungsi untuk mengambil, melakukan update dan menghapus data website. View berisikan Informasi yang ditampilkan kepada pengunjung website yang berisiakan variabel-variabel berisikan data. Didalam view ini dilarang menampilkan kode untuk melakukan koneksi ke basis data. Sedangkan controller sebagai penghubung antara model dan view terdapat class dan fungsi yang digunakan untuk memproses permintaan dari view ke dalam struktur data di dalam model.

\subsection{BLACK BOX TESTING}

Merupakan pengujian yang difokuskan untuk mengetahui apakah semua fungsi pada sistem atau perangkat lunak telah berjalan sesuai dengan kebutuhan fungsional (Kumar, et al., 2015) yang telah didefinisikan dahulu (Sommerville, 2015) (Rouf, 2012). Penguji tidak perlu mengenali seluk beluk sistem secara utuh hanya fokus pada fitur utamanya (Zulfikar \& Supianto, 2018). 


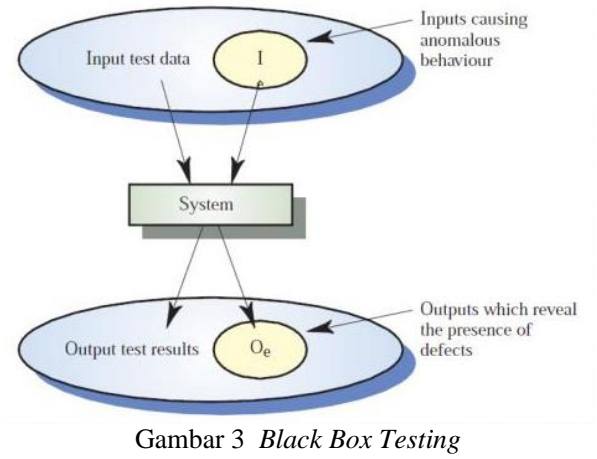

Dimana seperti pada Gambar 3. menggambarkan dalam penemuan kesalahan-kesalahan dan dapat dipantau dari fungsi-fungsi yang tidak benar atau hilang, kesalahan interface, kesalahan dalam struktur data, kesalahan terminasi dan inisialisasi, validitas fungsional, kesensitifan sistem terhadap nilai input tertentu dan batasan dari suatu data.

\section{PERANCANGAN SISTEM \\ 3.1. Analisa kebutuhan Sistem}

Paperless try out system untuk evaluasi hasil belajar siswa menggunakan MVC dikembangkan untuk membantu melakukan simulasi ujian nasional. Dalam pengembangannya, informasi kebutuhan fungsional yang harus dimiliki oleh paperless try out system seperti yang digambarkan pada Gambar 5 yang menggambarkan use case dari paperless try out system.

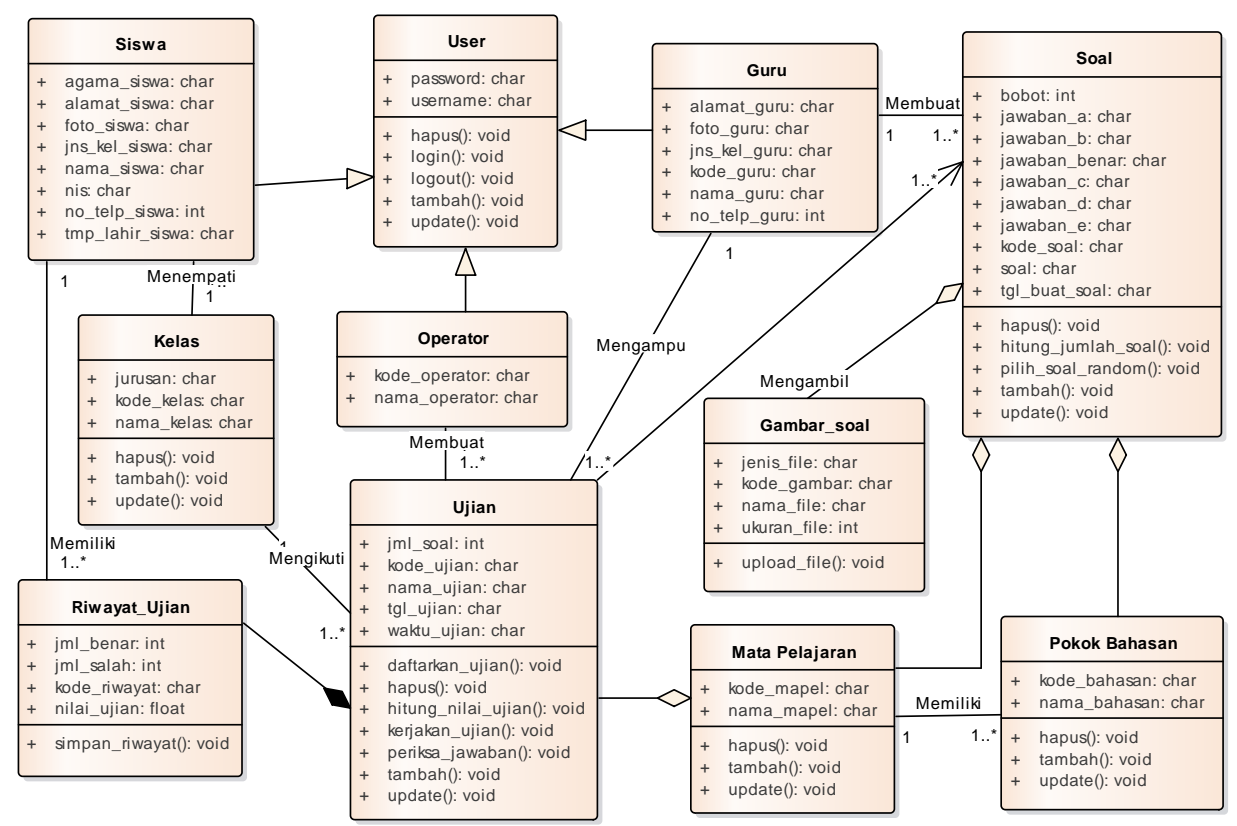

Gambar 4 Class Diagram Sistem

Berikut kebutuhan fungsional pada paperless try out system :

1) fitur pengelolaan data kependidikan sekolah. Pada bagian ini dapat dilakukan pendataan siswa, guru, kelas, mata pelajaran, dan pokok bahasan yang terdapat pada sekolah dimana fitur ini memiliki prioritas tinggi pengerjaannya karena sebagai data master.

2) fitur manajemen pengguna. Merupakan fasilitas atau layanan yang disediakan untuk dapat mengelola pengguna dalam hal ini siswa dan guru. Pembuatan pengguna dilakukan secara otomatis saat melakukan pendataan sisa maupun guru dengan username dan password berdasarkan Nomor induk siswa atau nomor unik pendidik dan tenaga kependidikan pada guru yang nantinya dapat diubah setelah user tersebut login ke sistem.

3) fitur bank soal ujian. Pada fitur ini, guru maupun operator dapat memasukkan soal ke database, sehingga ketikan akan mengadakan ujian, soal dapat diambil dari bank soal.
4) fitur ujian online. Dihadirkan untuk melatih siswa agar terbiasa mengerjakan ujian secara online, siswa akan mendapatkan hasil nilai dan evaluasi jawaban setiap soal yang dikerjakan. Ujian yang telah selesai secara otomatis akan tersimpan sebagai riwayat tes.

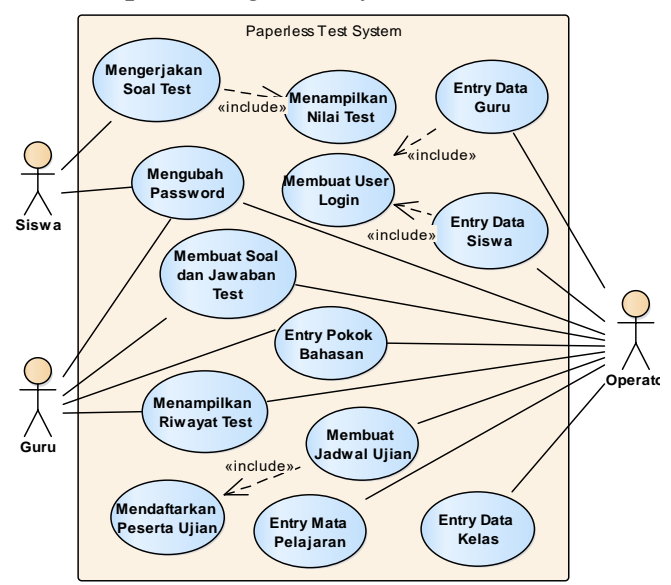

Gambar 5 Use Case Diagram Sistem 


\subsection{Desain class diagram}

Pada Gambar 4 menggambarkan kelas-kelas yang diimplementasikan dalam pembuatan database pada paperless try out system meliputi class User yang memiliki atribut dan operation yang dapat diwariskan kepada class Siswa, Operator dan Guru. Siswa, Operator dan Guru merupakan kategori pengguna yang nantinya berperan sebagai aktor dalam sistem.

Terdapat pula class Kelas, Ujian, Riwayat_Ujian, Soal, Gambar_soal, Pokok_Bahasan, dan Mata pelajaran yang saling berhubungan. Class Siswa berasosiasi dengan class Kelas dan class Riwayat Ujian. Selain itu, class Kelas memiliki hubungan asosiasi dengan class Ujian. Dan class Riwayat_Ujian merupakan bagian class Ujian yang wajib (composition). Class Guru memiliki hubungan asosiasi dengan class Soal dan class Ujian dengan nama masing-masing membuat dan mengampu. Class Operator memiliki relasi asosiasi membuat pada class Ujian. Class Ujian mempunyai relasi asosiasi searah (directional association) dengan nama mengambil pada class Soal dan merupakan bagian dari class Mata Pelajaran (aggregation). Class Mata Pelajaran, Pokok Bahasan, dan Gambar_soal merupakan bagian dari Class Soal (aggregation).

\subsection{Arsitektur MVC}

\section{1) Model}

Bagian ini berisikan pengelolaan data dengan sistem query basis data, yaitu proses ambil, simpan, hapus dan pencarian data yang ditampilkan pada Error! Not a valid bookmark self-reference.

Tabel 1 Fungsi Model Paperless Try Out System

\begin{tabular}{cll}
\hline No. & Class & Keterangan \\
\hline 1 & guru_model.php & $\begin{array}{l}\text { Fungsi query dalam menambah, } \\
\text { edit, tampil dan hapus data guru. }\end{array}$ \\
2 & kelas_model.php & $\begin{array}{l}\text { Fungsi query dalam menambah, } \\
\text { edit, tampil dan hapus data kelas }\end{array}$ \\
3 & login.php & $\begin{array}{l}\text { Fungsi query dalam membaca } \\
\text { data pada user }\end{array}$ \\
4 & mapel_model.php & $\begin{array}{l}\text { Fungsi query dalam menambah, } \\
\text { edit, tampil dan hapus data mata } \\
\text { pelajaran }\end{array}$ \\
5 & materi_model.php & $\begin{array}{l}\text { Fungsi query dalam menambah, } \\
\text { edit, tampil dan hapus data materi }\end{array}$ \\
6 & history_php & $\begin{array}{l}\text { Fugsi query dalam menampilkan } \\
\text { data ujian yang sudah terlaksana }\end{array}$ \\
7 & profil_model.php & $\begin{array}{l}\text { Fungsi query dalam edit dan } \\
\text { tampil data user }\end{array}$ \\
8 & siswa_model.php & $\begin{array}{l}\text { Fungsi query dalam menambah, } \\
\text { edit, tampil dan hapus data siswa }\end{array}$ \\
9 & soal_model.php & $\begin{array}{l}\text { Fungsi query dalam menambah, } \\
\text { edit, tampil dan hapus data soal } \\
\text { Fungsi } \\
\text { menampilkan data soal, guru dan } \\
\text { menambahkan data jawaban pada } \\
\text { data ujian }\end{array}$ \\
10 & ujian_model.php &
\end{tabular}

2) View

Pada bagian view terdiri dari beberapa package seperti guru, kelas, mapel, materi, siswa, soal, tampilan user dan ujian yang digunakan dalam pengelolaan tampilan pada sistem berupa form view, tambah dan edit. Berikut bagian dari view yang dapat dilihat pada Gambar 6 berikut :

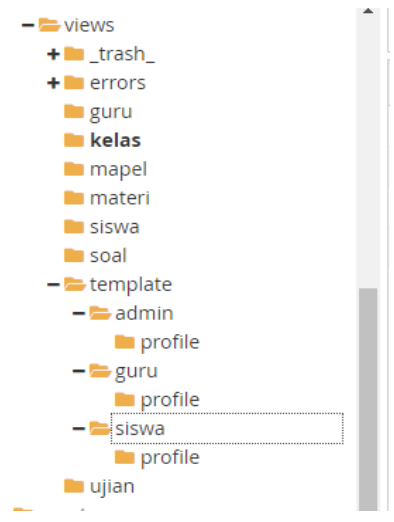

Gambar 6 Class view dalam sistem

\section{3) Controller}

Bagian ini berisikan controller yang berfungsi untuk meghubungkan bagian view dan model yang dituangkan pada Tabel 2

Tabel 2 Controller Paperless Try Out Sistem

\begin{tabular}{cll}
\hline No. & Class & Keterangan \\
\hline 1 & Guru.php & Mengelola pendataan guru \\
2 & Kelas.php & Mengelola pendataan kelas \\
3 & Login.php & Untuk pengguna masuk ke dalam sistem \\
4 & Mapel.php & Mengelola pendataan mata pelajaran \\
5 & Materi.php & Mengelola pendataan materi \\
6 & History.php & Mengelola data hasil ujian \\
7 & Profile.php & Mengelola data user \\
8 & Siswa.php & Menngelola pendataan siswa \\
9 & Soal.php & Mengelola pendataan soal \\
10 & Ujian.php & Mengatur penjadwalan dan mengijinkan \\
& & siswa mengikuti ujian \\
\hline
\end{tabular}

\section{HASIL DAN PEMBAHASAN}

Hasil dari rancang bangun paperless try out system ini dituangkan dalam bentuk interface sistem. Pada Gambar 7 menampilkan halaman login pada saat sistem ini dibuka yang terdiri dari 3 pilihan user yaitu admin, guru dan siswa.

Ketika login sudah berhasil dilakukan maka akan muncul tampilan beranda pada sistem yang berisikan ucapan selamat datang dan juga diskripsi dari sistem yang dituangkan pada Gambar 8 .

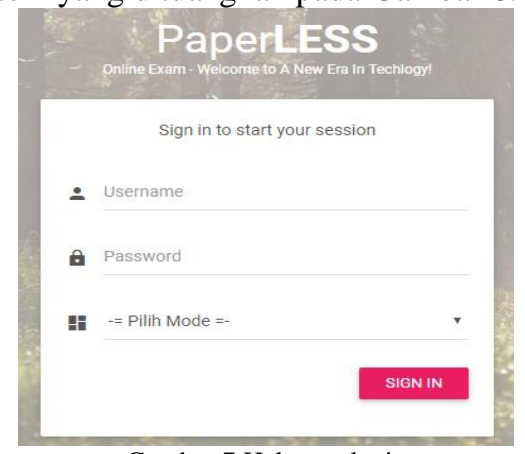

Gambar 7 Halaman login 

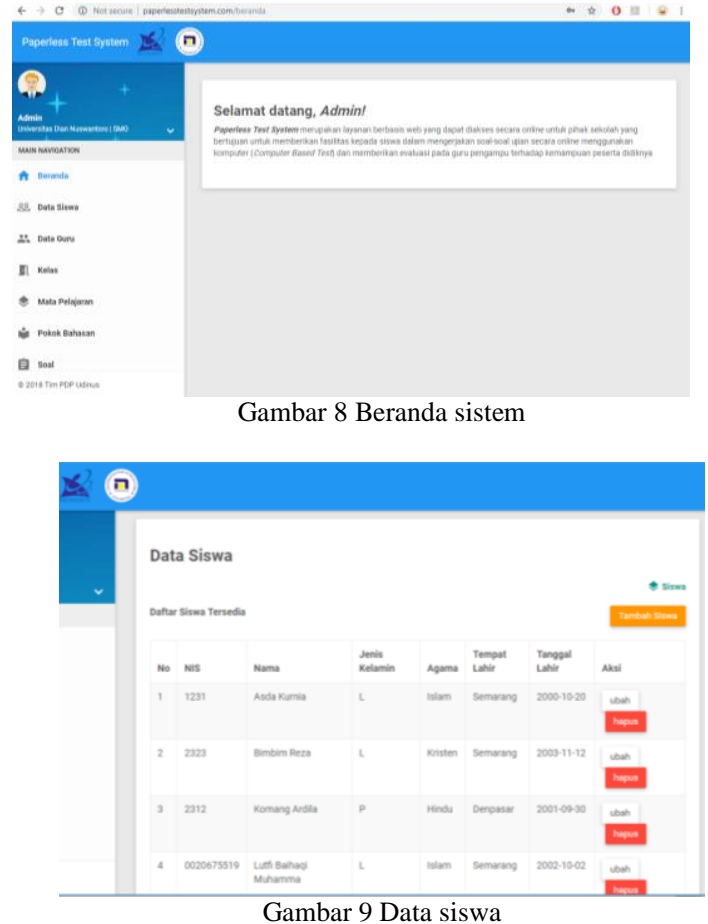

Fitur- fitur yang terdapat pada sistem ini yaitu pada pengelolaan data kependidikan sekolah yang digambarkan pada gambar 9-12.

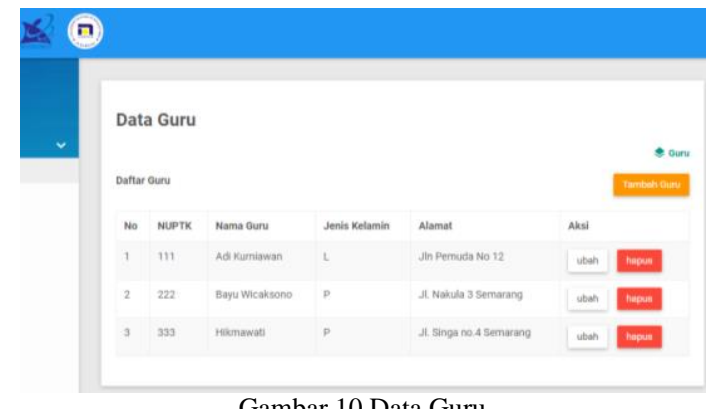

Gambar 10 Data Guru

Pada Gambar 10 berisikan data master guru yang sudah terdata atau terdaftar. Dimana tersedia fasilitas untuk menambahkan, menghapus dan mengubah data guru. Pada Gambar 11 berisikan data master kelas yang sudah terdata atau terdaftar. Dimana tersedia fasilitas untuk menambahkan, menghapus dan mengubah data kelas.

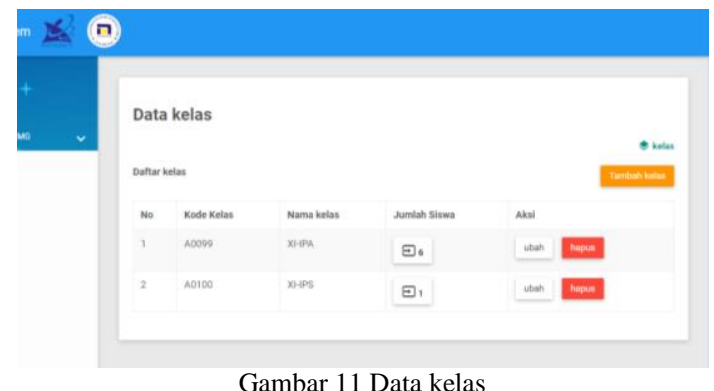



Pada Gambar 12 data master mata pelajaran yang sudah terdata atau terdaftar. Dimana tersedia fasilitas untuk menambahkan, menghapus dan mengubah data mata pelajaran.

Gambar 13 berisikan data master pokok bahasan yang sudah tedaftar. Dimana tersedia fasilitas untuk menambah, menghapus dan mengubah data pokok bahasan atau materi. Dari segi fitur manajemen pengguna yang termasuk dalam fungsional sistem terdapat akses untuk mengubah password untuk menjadikan lebih aman lagi dari akun usernya yang ditampilkan pada Gambar 14.



Gambar 13 Data Pokok Bahasan
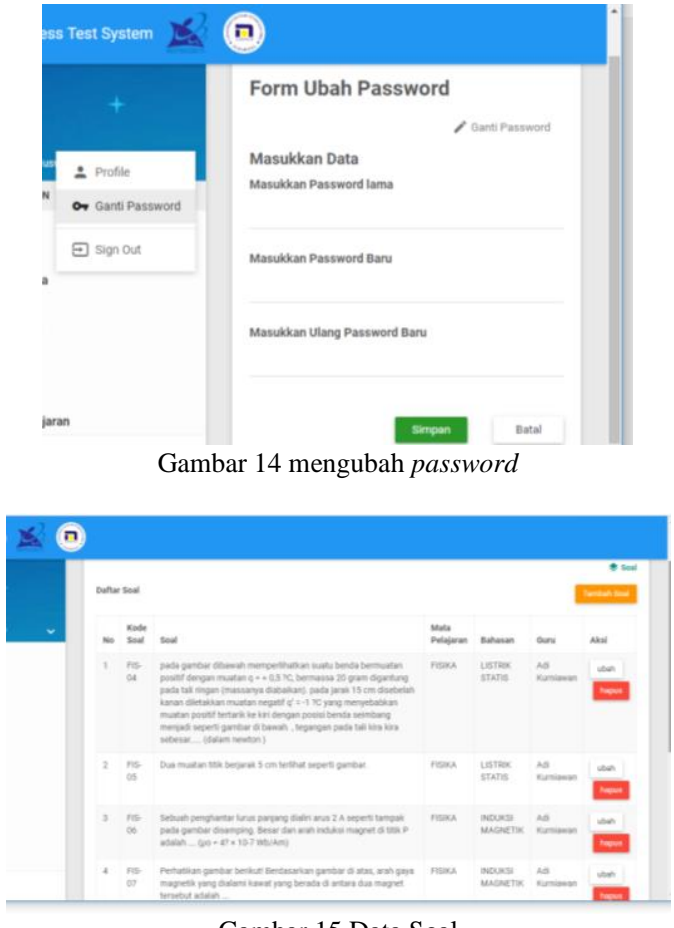
Pada Gambar 15 menampikan fitur bank soal yang berisikan data master soal-soal yang sudah dibuat dan disimpan pada database. Dimana tersedia fasilitas untuk menambah ataupun menghapus data soal. Setiap soal yang dibuat memiliki bobot nilai 1 (satu).

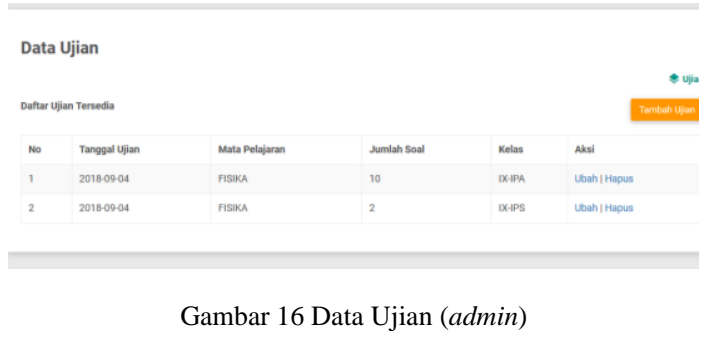

Pada Gambar 16 menampilkan data ujian yang diakses dengan user admin. Data ujian ini merupakan bagian dari fitur ujian online. Setiap data ujian tersebut, admin dapat mengubah maupun menghapus data ujian. Terdapat juga tombol Tambah Ujian yang digunakan untuk membuat ujian. Jika tombol Tambah Ujian ditekan maka akan tampil Form Tambah Data Ujian seperti pada Gambar 20.

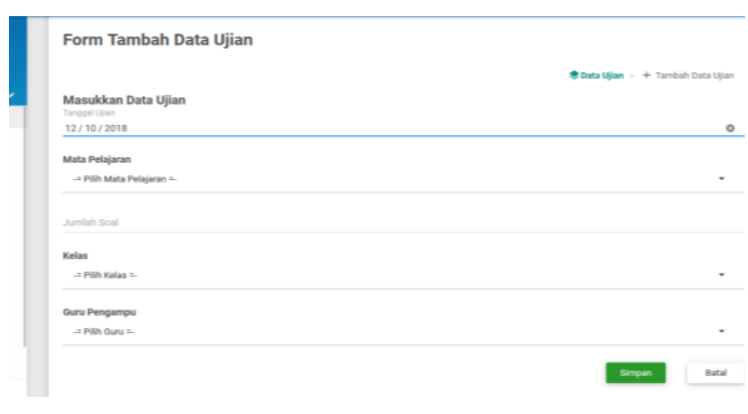

Gambar 17 Form Tambah Data Ujian

Pada Gambar 20, user admin dapat membuat ujian dengan cara memasukkan tanggal ujian, memilih mata pelajaran yang diujikan, menulis jumlah soal yang akan diujikan, memilih kelas yang akan ujian dan guru pengampu serta menekan tombol Simpan. Selanjutnya sistem akan mengambil soal dari bank soal sesuai dengan jumlah soal ujian. Jika bank soal tidak mempunyai jumlah soal yang diminta, maka sistem memberi pesan bahwa soal tidak cukup. Namun jika jumlah soal mencukupi, maka sistem akan menyimpan data ujian dan akan memilih soal secara random dari bank soal menggunakan fungsi mysql rand().

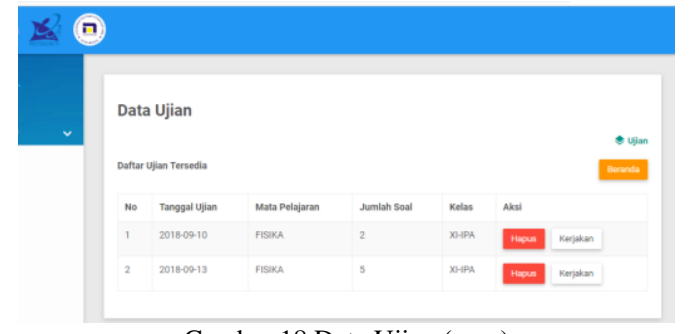

Gambar 18 Data Ujian (user)
Pada gambar 18 menampilkan data ujian yang tersedia pada saat user siswa melakukan login. Data ujian untuk user siswa tidak terdapat tombol Tambah Ujian seperti user admin. Pada data ujian, siswa dapat melakukan ujian dengan menekan tombol kerjakan. Setelah melakukan aksi tersebut, muncul tampilan petunjuk pengerjaan seperti pada gambar 19.

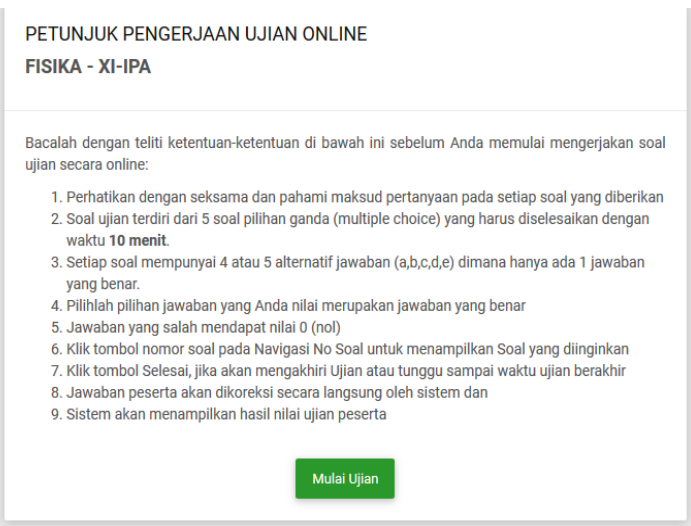

Gambar 19 Petunjuk Pengerjaan

Pada gambar 19 menampilkan Petunjuk Pengerjaan Ujian. Jika siswa telah memahami petunjuk pengerjaan, maka selanjutnya siswa dapat menekan tombol Mulai Ujian. Selanjutnya sistem akan menampilkan daftar soal ujian beserta waktu pengerjaan (timer) seperti pada gambar 20. Nilai timer secara otomatis akan muncul berdasarkan jumlah soal dikali dua menit. Dua menit merupakan waktu yang diberikan untuk mengerjakan tiap soal. Pada Gambar 20, siswa memilih 1 (satu) pilihan jawaban yang benar pada setiap nomornya. Jika soal ujian telah selesai dikerjakan, siswa dapat menekan tombol Selesai. Selanjutnya sistem akan menghitung total nilai yang telah dikerjakan. Metode perhitungan total nilai menggunakan rumus:

Total Nilai $=\frac{\text { Jumlah No Benar }}{\text { Jumlah Soal }} \times 100$

Pada Gambar 21 menampilkan hasil test atau ujian dari proses mengerjakan soal dimana hasil tersebut akan langsung muncul setelah ujian selesai. Dari gambar tersebut terlihat bahwa total nilai 20 dikarenakan dalam percobaan hanya memilih hanya 5 soal dan hanya 1 soal yang benar. Selanjutnya sistem akan menyimpan hasil ujian yang telah dikerjakan oleh user siswa ke menu riwayat ujian seperti yang ditampilkan pada gambar 22 . 
284 Jurnal Teknologi Informasi dan Ilmu Komputer (JTIIK), Vol. 6, No. 3, Juni 2019, hlm. 277-286

\begin{tabular}{|c|c|c|c|c|}
\hline \multirow{2}{*}{ Waktu Ujian : 09:52 } & \multicolumn{4}{|c|}{ Tabel 3 Test Case pengujian validasi } \\
\hline & no & Kasus Uji & Kondisi & Hasil \\
\hline FISIKA - IX-IPA & 1 & Login & User dapat melakukan login & Valid \\
\hline \multirow{2}{*}{ 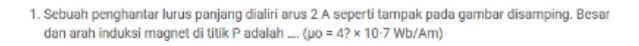 } & & & sesuai dengan username dan & \\
\hline & & & password yang diberikan & \\
\hline $\begin{array}{l}\text { a. } 08 \times 10-5 \text { t masuk bidang kertas } \\
\text { b. } 6 \times 10.5 \text { T keluas bidang kettas }\end{array}$ & 2 & Profil & User dapat mengganti & valid \\
\hline b. $06 \times 10.5$ T, keluas bidang kertas & & & password lama & \\
\hline \multirow{2}{*}{ d. O $2 \times 10.5$ T, keluer bidang kertas } & 3 & List Siswa & Menampilkan data siswa sesuai & Valid \\
\hline & & & dengan database & \\
\hline 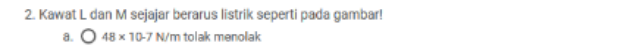 & 4 & CRUD Siswa & $\begin{array}{l}\text { Proses penambahan, } \\
\text { pengubahan dan penghapusan }\end{array}$ & Valid \\
\hline b. $\mathrm{O} 24 \times 10.7 \mathrm{~N} / \mathrm{m}$ tarik menarik & & & data siswa & \\
\hline \multirow{2}{*}{$\begin{array}{l}\text { c. } 048 \times 10.6 \mathrm{~N} / \mathrm{m} \text { tarik menarik } \\
\text { d. } \mathrm{O} 36 \times 10.6 \mathrm{~N} / \mathrm{m} \text { tolak menolak }\end{array}$} & 5 & List Guru & Menampilkan data guru sesuai & Valid \\
\hline & & & dengan database & \\
\hline 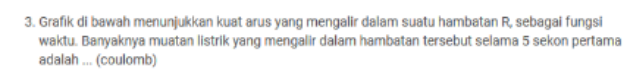 & 6 & CRUD Guru & $\begin{array}{l}\text { Proses penambahan, } \\
\text { pengubahan dan penghapusan } \\
\text { data guru }\end{array}$ & valid \\
\hline $\begin{array}{l}\text { adalah } \ldots \text { (coullomb) } \\
\text { a. } \mathrm{O}_{8}\end{array}$ & 7 & List Kelas & Menampilkan data kelas sesuai & Valid \\
\hline b. $\mathrm{O}_{10}$ & & & dengan database & \\
\hline c. $\mathrm{O}_{14}$ & 8 & CRUD Kelas & Proses penambahan, & Valid \\
\hline d. $O_{18}$ & & & pengubahan dan penghapusan & \\
\hline e. $\mathrm{O}_{20}$ & & & data guru & \\
\hline \multirow{2}{*}{$\begin{array}{l}\text { 4. Grafik di bawah menunilukkan kuat arus yang mengalir dalam suatu hambatan R, sebagas fungsi } \\
\text { wakhu Banyaknya muatan listrik yang mengalir dalam hambatan tersebut selama } 5 \text { sekon pertama } \\
\text { adalah ... (coulomb) }\end{array}$} & 9 & $\begin{array}{ll}\text { List } & \text { Data } \\
\text { Kelas } & \end{array}$ & Menampilkan data & valid \\
\hline & 10 & CRUD Mata & penambahan, & Valid \\
\hline & & Pelajaran & pengubahan dan penghapusan & \\
\hline c. $\mathrm{O}_{14}$ & & & data mata pelajaran & \\
\hline $\begin{array}{l}\text { d. }{ }_{18} 18 \\
\text { e. } O 20\end{array}$ & 11 & List Pokok & Menampilkan data pokok & Valid \\
\hline e. 0.20 & & bahasan & bahasan & \\
\hline \multirow{3}{*}{$\begin{array}{l}\text { 5. Dari percobaan hubungan tegangan( }(V) \text { dengan kuat arus () pada resistor, dihasilkan grafik } V-1 \\
\text { pada gambar di bawah. Jika } V=5,0 \text { volt, maka besar kuat arus yang mengalir adalah -. } \\
\text { a. } O 5 \mathrm{~mA} \\
\text { b. } O 10 \mathrm{~mA}\end{array}$} & 12 & CRUD Pokok & Proses penambahan, & Valid \\
\hline & & Bahasan & pengubahan dan penghapusan & \\
\hline & & & data pokok bahasan & \\
\hline $\begin{array}{l}\text { c. } \mathrm{O}_{20 \mathrm{~mA}} \\
\text { d. O } 40 \mathrm{~mA}\end{array}$ & 13 & List Soal & Menampilkan semua data soal & Valid \\
\hline \multirow{3}{*}{ e. $035 \mathrm{~mA}$} & & & yang sudah dibuat & \\
\hline & 14 & CRUD Soal & penambahan, & Valid \\
\hline & & & pengubahan dan penghapusan & \\
\hline Salessai / Lhat Nilai & & $J \cdot \mathrm{I}$ & data soal & \\
\hline & 15 & List Ujian & Menampilkan daftar ujian yang & Valid \\
\hline \multirow{2}{*}{ Gambar 20 Mengerjakan soal } & 16 & CRIDD Uiian & & Iolid \\
\hline & 10 & CNUD UJIaII & pengubahan dan penghapusan & vandu \\
\hline \multirow{3}{*}{ HASIL PENGERJAAN UJIAN ONLINE } & & & & \\
\hline & 17 & Riwayat & Menampilkan hasil ujian yang & Valid \\
\hline & & Ujian & terlah terlaksana & \\
\hline
\end{tabular}

Dari segi masalah kegunaan dalam desain antarmuka sistem yang melibatkan evaluasi anatarmuka dan kepatuhan dengan prinsip-prinsip usability dari 10 heuristic evaluation yang dikembangkan oleh Jacob Nielsen menghasilkan beberapa hasil evaluasi yang dituangkan pada Tabel 4.

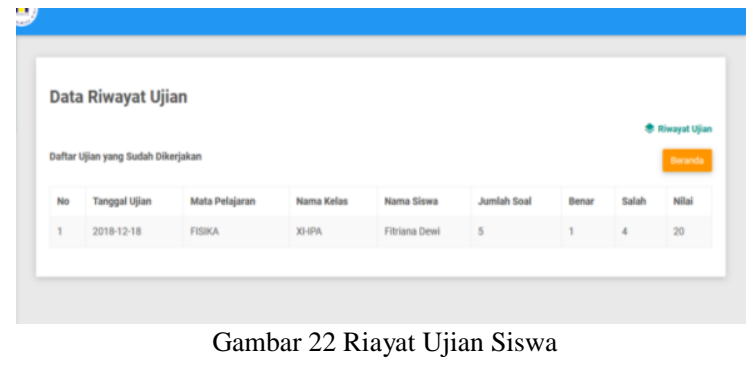

\section{PENGUJIAN SISTEM}

Tahapan akhir dari rancang bangun paperless try out system ini adalah pengujian. Hasil dari pengujian blackbox dapat dilihat pada Tabel 3. Dan dari segi fungsional antarmuka yang dapat dilihat pada tabel 4 .

Tabel 4 Heuristik Testing

\begin{tabular}{|c|c|c|c|}
\hline No. & Prinsip & Ada? & Bagaimana? \\
\hline 1 & $\begin{array}{l}\text { Visibility Of System } \\
\text { Status }\end{array}$ & $\mathrm{Ya}$ & $\begin{array}{l}\text { Sistem sudah memberikan } \\
\text { umpan balik dalam } \\
\text { pemberian warna font pada } \\
\text { navigasi ketika memilih } \\
\text { menu dan loading screen } \\
\text { saat melakukan koneksi ke } \\
\text { database. }\end{array}$ \\
\hline 2 & $\begin{array}{l}\text { Match between } \\
\text { system and } \\
\text { realworld }\end{array}$ & $\mathrm{Ya}$ & $\begin{array}{l}\text { Sistem sudah menggunakan } \\
\text { bahasa yang familiar yang } \\
\text { digunakan pengguna. }\end{array}$ \\
\hline 3 & $\begin{array}{l}\text { User Control And } \\
\text { Freedom }\end{array}$ & $\mathrm{Ya}$ & $\begin{array}{l}\text { User admin bebas dalam } \\
\text { melakukan penambahan, } \\
\text { penghapusan, dan } \\
\text { perubahan data namun } \\
\text { belum terdapat suatu fungsi } \\
\text { yang dapat mengembalikan } \\
\text { data yang sudah dihapus. } \\
\text { menghapus data. }\end{array}$ \\
\hline
\end{tabular}




\begin{tabular}{|c|c|c|c|}
\hline No. & Prinsip & Ada? & Bagaimana? \\
\hline 4 & $\begin{array}{l}\text { Consistency and } \\
\text { Standart }\end{array}$ & $\mathrm{Ya}$ & $\begin{array}{l}\text { Semua tombol, tampilan, } \\
\text { teks dan warna dalam suatu } \\
\text { halaman sudah terlihat sama } \\
\text { pada beberapa halaman. }\end{array}$ \\
\hline 5 & Error Prevention & $\mathrm{Ya}$ & \begin{tabular}{llr} 
Pada saat melakukan & \multicolumn{2}{c}{ penambahan data form } \\
sudah menampilkan & contoh \\
tipe teks yang & akan \\
diinputkan & ke & dalam \\
database. & & \\
\end{tabular} \\
\hline 6 & $\begin{array}{l}\text { Recognitionrather } \\
\text { than Recall }\end{array}$ & $\mathrm{Ya}$ & $\begin{array}{l}\text { User tidak perlu mengingat } \\
\text { tampilan seluruh tombol, } \\
\text { karena sudah disesuiakan } \\
\text { dengan fungsinya. }\end{array}$ \\
\hline 7 & $\begin{array}{l}\text { Flexibiity and } \\
\text { efficiency of use }\end{array}$ & Ya & $\begin{array}{l}\text { Dalam mengerjakan soal } \\
\text { pada sistem dimudahkan } \\
\text { dalam pemilihan jawaban } \\
\text { dengan pilihan, tanpa } \\
\text { melakukan pengetikan. Dan } \\
\text { pada saat penambahan data } \\
\text { soal dapat melakukan } \\
\text { dengan shortcut Ctrl+c dan } \\
\text { Ctrl+v untuk memudahkan } \\
\text { pemindahan teks. }\end{array}$ \\
\hline 8 & $\begin{array}{l}\text { Aesthethic and } \\
\text { minimalis design }\end{array}$ & $\mathrm{Ya}$ & $\begin{array}{l}\text { Desain sangat sederhana } \\
\text { dengan latar belakang puth } \\
\text { untuk memudahkan } \\
\text { pandangan dan sedikit } \\
\text { dalam pewarnaan menu. }\end{array}$ \\
\hline 9 & $\begin{array}{l}\text { Help users } \\
\text { recognize, diagnose, } \\
\text { and recover from } \\
\text { errors }\end{array}$ & $\mathrm{Ya}$ & $\begin{array}{l}\text { Terdapat pesan validasi } \\
\text { apabila pada saat login } \\
\text { terjadi username atau } \\
\text { password salah ataupun } \\
\text { belum diisikan. }\end{array}$ \\
\hline 10 & $\begin{array}{l}\text { Help and } \\
\text { Documentation }\end{array}$ & Tidak & $\begin{array}{l}\text { Hanya tersedia petunjuk } \\
\text { pada saat pengerjaan soal } \\
\text { saja. }\end{array}$ \\
\hline
\end{tabular}

Dari hasil pada tabel 4 Tabel 4 menunjukkan bahwa sudah mencapai $90 \%$ dari prinsip usability telah diimplementasikan.

\section{KESIMPULAN}

Dari hasil pembahasan pada rancang bangun paperless try out system ini dapat diperoleh kesimpulan. Rancang bangun ini dibuat berdasarkan kebutuhan siswa untuk simulasi ujian nasional dengan menggunakan arsitektur MVC. Arsitektur MVC terbukti dapat mengurangi kompleksitas program dan membuat program menjadi modular, sehingga mudah untuk dikelola dan disesuaikan dengan perubahan.

\section{UCAPAN TERIMA KASIH}

Penelitian ini dibiayai oleh Direktorat Jenderal Penguatan Riset dan Pengembangan, Kementerian Riset, Teknologi dan Pendidikan Tinggi Nomor SP DIPA-042.06.1.401516/2018 dan nomor kontrak 053/A.38.04/UDN-09/II/2018, di LPPM Universitas Dian Nuswantoro Semarang.

\section{DAFTAR PUSTAKA}

ARIEF, R. \& SURYANI, E., 2016. Sistem Dinamik Ujian Nasional Berbasis Komputer Untuk Meminimalkan Resiko Kecurangan Serta
Meningkatkan Efektifitas Dan Efisiensi Anggaran. Integer Journal, 1(2), pp. 67-75.

ASWATI, S. \& SIAGIAN, Y., 2016. Model Rapid Application Development Dalam Rancang Bangun Sistem Informasi Pemasaran Rumah (Studi Kasus : Perum Perumnas Cabang Medan). Surabaya, s.n., pp. 317323.

DENNIS, A., WIXOM, B. H. \& ROTH, R. M., 2009. System Analysis And Design. 4th penyunt. s.l.:John Wiley and Sons.

DEWI, M. A., CAHYADI, D. \& WUKANSARI, Y., 2014. Sistem Ujian Online Calon Mahasiswa Baru Berbasis Ilearning Education Marketing Pada Perguruan Tinggi. Creative Communication and Innovative Technology (CCIT), 8(1), pp. 116-329.

G., LAWI, A. \& A., 2016. Analisis Arsitektur Aplikasi Web Menggunakan Model View Controller (MVC) pada Framework Java Server Faces. Scientific Journal of Informatics, pp. 55-67.

HAMEED, M., ABRAR, M., SIDDIQ, A. \& JAVEED, T., 2014. MVC Software Design Pattern in Web Application Development. International Journal of Scientific \& Engineering Research (IJESER), May, 5(5), pp. 17-20.

HASMIAH, 2014. Pengaruh Try Out Terhadap Peningkatan Nilai Hasil Ujian Nasional. Jurnal Ilmiah Administrasita, 4(1), pp. 4661.

JAILIA, M., KUMAR, A., SINGHAL, H. \& AGARWAL, M., 2016. Development and Performance Analysis of Cloud and MVC Based Web application. Udaipur, ACM, pp. $1-5$.

KUMAR, M., SINGH, S. K. \& DWIVEDI, R. K., 2015. A Comparative Study of Black Box Testing and White Box Testing Techniques. (IJARCSMS) International Journal of Advance Research in Computer Science and Management Studies, pp. 32-44.

NARIMO, F., B. \& SAPTI, M., 2014. Hubungan Nilai Try Out Terhadap Nilai Ujian Nasional Mata Pelajaran Matematika Siswa Smp Di Kecamatan Sapuran. Ekuivalen, 9(1), pp. 3844.

NOERTJAHYANA, A., 2002. Studi Analisis Rapid Aplication Development Sebagai Salah Satu Alternatif Metode Pengembangan Perangkat Lunak. Jurnal Infromatika, 3(2), pp. 74-79.

P., $2017 . \quad$ inionline.id. [Online] Available at: http://inionline.id/2017/03/inilah-dampaknegatif-pelaksanaan-unbk-pada-pelajar/ [Diakses 1812 2018].

PAKPAHAN, R., 2016. Model Ujian Nasional Berbasis Komputer: Manfaat dan 
Tantangan. Jurnal Pendidikan dan Kebudayaan, 1(1), pp. 19-35.

PRASETYA, I. G. Y. E., 2011. Desain Dan Implementasi Sistem Informasi Perpustakaan Berbasis Web Dengan MVC (Model View Controler). Jurnal Teknologi Dan Informatika (TEKNOMATIKA), 1(2), pp. 125-147.

PRESSMAN, R. S., 2014. Software Engineering a Practitioner's Approach. s.l.:McGraw-Hill Education.

PUTRI, S. I. \& S, Y. A., 2016. Perancangan Sistem Perpustakaan Online Menggunakan Metode Model View Controller (MVC) Studi Kasus STMIK Asia Malang. Jurnal Ilmiah Teknologi dan Informasia ASIA (JITIKA), Agustus, 10(2), pp. 17-23.

RAHARJO, S. T., 2012. Tryout Ujian Nasional Berbasis Web, Surakarta: Fakultas Teknik Jurusan Teknik Elektro Universitas Muhammadiyah Surakarta.

RIDHO, A. N., 2011. Digilib Unnes. [Online] Available at: https://lib.unnes.ac.id/7377/ [Diakses 1712 2018].

ROUF, A., 2012. Pengujian Perangkat Lunak Dengan Menggunakan Metode White Box Dan Black Box. HIMSYATECH - Jurnal Teknologi Informasi, pp. 1-7.

SANI, R. R. \& KURNIAWAN, D., 2018. Analysis And Design Of Online Exam System At School Using Unified Model. Yogyakarta, s.n., pp. 198-203.

SEPTANTO, H. \& ANANTO, P. D., 2015. Multimedia Based Application Design of Selection Examination as A Support for Paperless Office in PPKD East Jakarta. s.1., s.n., pp. 125-133.

SOMMERVILLE, I., 2015. Software Engineering. 10th penyunt. s.l.:Addison-Wesley.

SOPHAN, M. K. \& KURNIAWATI, A., 2018. Perancangan Aplikasi Learning By Doing Interaktif Untuk Mendukung Pembelajaran Bahasa Pemrograman. Jurnal Teknologi Informasi dan Ilmu Komputer (JTIIK), 5(2), pp. 163-169.

UTOMO, D. W. \& KUSTIJONO, R., 2015. pengembangan sistem ujian online soal pilihan ganda dengan menggunakan software wondershare quiz creator. Jurnal Inovasi Pendidikan Fisika (JIPF), 4(3), pp. 1-6.

WEIDONG, Z., 2010. The Application of Modern Teaching Techniques in Computer Foundaton Education. International Conference on Educational and Information Technology (ICEIT 2010), pp. 245-247.

WIDIKDA, A. P., AKHYAR, M. \& ESTRIYANTO, Y., 2013. Evaluasi Pelaksanaan Ujian Online Dengan Menggunakan Learning Management System Moodle Pada Mata
Kuliah Pneumatik Hidrolik. Jurnal Nosel, 2(1).

YULIA, E., R. \& NASIR, M., 2016. Hubungan antara Hasil Uji Kognitif Try Out Ujian Nasional (UN) dengan Hasil Ujian Nasional (UN) Mata Pelajaran Kimia SMA Kota Banda Aceh Tahun Ajaran 2014/2015. Jurnal Ilmiah Mahasiswa Pendidikan Kimia (JIMPK), 1(3), pp. 35-42.

ZHANG, A., 2017. The Design and Application of Paperless Examination System. s.1., Atlantis Press, pp. 1449-1453.

ZULFIKAR, R. A. \& SUPIANTO, A. A., 2018. Rancang Bangun Aplikasi Antrian Poliklinik Berbasis Mobile. Jurnal Teknologi Informasi dan Ilmu Komputer, 5(3), pp. 361-370. 